\title{
Staphylococcus devriesei sp. nov., isolated from teat apices and milk of dairy cows
}

\author{
Karlien Supré, ${ }^{1}$ Sarne De Vliegher, ${ }^{1}$ Ilse Cleenwerck, ${ }^{2}$ Katrien Engelbeen, ${ }^{2}$ \\ Stefanie Van Trappen, ${ }^{2}$ Sofie Piepers, ${ }^{1}$ Otlis C. Sampimon, ${ }^{3}$ \\ Ruth N. Zadoks, ${ }^{4}$ Paul De Vos ${ }^{2}$ and Freddy Haesebrouck ${ }^{5}$ \\ ${ }^{1}$ Department of Reproduction, Obstetrics, and Herd Health, Faculty of Veterinary Medicine, \\ Ghent University, Salisburylaan 133, 9820 Merelbeke, Belgium \\ ${ }^{2}$ BCCM/LMG Bacteria Collection and Laboratory of Microbiology, Faculty of Sciences, \\ Ghent University, K. L. Ledeganckstraat 35, 9000 Ghent, Belgium \\ ${ }^{3}$ Animal Health Service, Deventer, The Netherlands \\ ${ }^{4}$ Royal (Dick) School of Veterinary Studies, University of Edinburgh, and Moredun Research \\ Institute, Penicuik, Scotland, UK \\ ${ }^{5}$ Department of Pathology, Bacteriology, and Avian Diseases, Faculty of Veterinary Medicine, \\ Ghent University, Belgium
}

Correspondence Karlien Supré Karlien.Supre@UGent.be
Ten non-motile, Gram-stain-positive, coagulase-negative staphylococci were isolated from bovine milk and teat apices. All isolates were catalase-positive, with anteiso- $C_{15: 0}$, iso- $C_{15: 0}$, anteiso$\mathrm{C}_{17: 0}$, iso- $\mathrm{C}_{17: 0}$ and $\mathrm{C}_{18: 0}$ as predominant fatty acids and diphosphatidylglycerol and phosphatidylglycerol as major polar lipids. The results of sequence analysis of the 16S rRNA gene and four housekeeping genes ( $r p o B$, hsp60, tuf and dnaJ) in combination with tRNA-intergenic spacer length analysis showed that the isolates form a separate branch within the genus Staphylococcus. Based on 16S rRNA gene sequencing, the phylogenetically most closely related species are Staphylococcus haemolyticus, S. hominis and S. lugdunensis, with $>98.7 \%$ sequence similarity. The DNA G $+C$ content varies from 33.3 to $33.7 \mathrm{~mol} \%$, and DNA-DNA hybridization with the nearest neighbours, based on 16S rRNA gene sequences, confirmed that the isolates represent a novel Staphylococcus species. All isolates induced a small zone of complete haemolysis on Columbia agar with $5 \%$ sheep blood and exhibited a homogeneous biochemical fingerprint that is discriminative from the phylogenetically most closely related species. Based on these results, it is proposed to classify the ten isolates as Staphylococcus devriesei sp. nov., with strain KS-SP $60^{\top}$ (=LMG $25332^{\top}=$ CCUG $58238^{\top}$ ) as the type strain.
Abbreviations: CNS, coagulase-negative staphylococci; tDNA-PCR, tRNA-intergenic spacer PCR.

The GenBank/EMBL/DDBJ accession numbers for the rpoB, hsp60, tuf, dnaJ and 16S rRNA gene sequences of isolates KS-SDV 16 and 19 and KS-SP $11,16,18,20,27,60^{\top}, 65$ and 66 are respectively FJ389223FJ389225, FJ389227-FJ389230 and FJ389232-FJ389234 (failed reaction for KS-SP 20) (rpoB), FJ389210, FJ389211 and FJ389215FJ389220 (failed reaction for KS-SP 27 and 66) (hsp60), FJ389240FJ389242, FJ389244-FJ389246 and FJ389248 (failed reaction for KS-SP 16, 65 and 66) (tuf), FJ907448-FJ907455 (failed reaction for KS-SDV 16 and KS-SP 66) (dnaJ) and FJ938168, FJ389197, FJ389198, FJ389200-FJ389203 and FJ389206-389208 (16S rRNA gene).

Details of strain isolation and amplification primers, phenotypic results for individual strains and dendrograms based on tDNA-PCR results and $d n a J, r p o B, h s p 60$ and tuf sequences are available as supplementary material with the online version of this paper.
In well-managed dairy farms in many parts of the world, coagulase-negative staphylococci (CNS) have become the predominant pathogens in milk samples from cows (Piepers et al., 2007; Schukken et al., 2009). Recent publications report on subclinical/clinical mastitis due to CNS (Gillespie et al., 2009), but beneficial effects have also been suggested (De Vliegher et al., 2003, 2004; Schukken et al., 2009). tRNA-intergenic spacer PCR (tDNA-PCR) has been shown to be useful for rapid, inexpensive and accurate identification of CNS at the species level (Supré et al., 2009). During a recent validation study applying the latter technique to 288 bovine field isolates from milk and teat apices, ten CNS isolates remained unidentified. The tDNA-PCR patterns of these isolates were highly similar to each other and closely related to those of Staphylococcus capitis, S. simulans, S. haemolyticus and S. xylosus, but they formed a well-defined, separate cluster (Supplementary 
Fig. S1, available in IJSEM Online), indicating that the ten isolates could represent an undefined Staphylococcus species. The aim of this study was to characterize these isolates further and to determine whether they constitute a hitherto-unknown CNS species.

The ten isolates originated from six animals from five herds in Belgium and the Netherlands. One isolate originated from milk of a subclinical infection of the udder (KS-SP 11) and nine originated from teat apices (Supplementary Table S1). The isolates were preliminarily identified as CNS following the guidelines of the NMC (a global organization for mastitis control and milk quality; http://www. nmconline.org/), including determination of catalase and coagulase activity and detection of haemolysis (Hogan et al., 1999).

After aerobic incubation at $35{ }^{\circ} \mathrm{C}$ for 24 and $48 \mathrm{~h}$ on Colombia agar with $5 \%$ sheep blood, all ten isolates showed homogeneous growth. After $48 \mathrm{~h}$ of incubation, colonies were circular with a diameter of 3-4 $\mathrm{mm}$, smooth and glistening, and they showed a small zone $(1 \mathrm{~mm})$ of complete haemolysis. The majority of the colonies were grey-yellow, but KS-SP 27, KS-SP 66 and KS-SDV 16 were yellow and KSSP 20 and KS-SP 65 showed a yellow to orange pigmentation. Incubation at $42{ }^{\circ} \mathrm{C}$ resulted in larger colonies, whereas incubation at $25{ }^{\circ} \mathrm{C}$ and under anaerobic conditions resulted in smaller colonies. All isolates were catalase-positive. Gramstaining and phase-contrast microscopy showed typical staphylococcal, non-spore-forming, non-motile, Gramstain-positive cells, occurring in pairs and small clusters.

The cellular fatty acid patterns of the ten isolates were determined as described previously (Mergaert et al., 2001). Cells were harvested from cultures grown on trypticase soy agar (BBL 11768) at $28{ }^{\circ} \mathrm{C}$ for $24 \mathrm{~h}$. All ten isolates possessed very similar fatty acid profiles, and the mean profile consisted of anteiso- $\mathrm{C}_{15: 0}(48.2 \%)$, anteiso- $\mathrm{C}_{17: 0}$ $(19.1 \%)$, iso- $\mathrm{C}_{17: 0} \quad(6.1 \%), \mathrm{C}_{18: 0} \quad(5.9 \%)$, iso- $\mathrm{C}_{15: 0}$ $(5.1 \%), \mathrm{C}_{20: 0}(3.6 \%)$, anteiso- $\mathrm{C}_{19: 0}(3.3 \%)$, iso- $\mathrm{C}_{16: 0}$ $(2.5 \%)$, iso- $\mathrm{C}_{19: 0}(1.9 \%)$, iso- $\mathrm{C}_{14: 0}(1.5 \%), \mathrm{C}_{16: 0}(1.4 \%)$ and iso- $\mathrm{C}_{18: 0}(1.1 \%)$, which corresponds to that of other CNS (Kotilainen et al., 1991).

Polar lipids were extracted and separated by using twodimensional TLC according to Tindall (1990a, b). The total lipid profile was visualized by spraying with molybdatophosphoric acid and further characterized by spraying with ninhydrin (specific for amino groups), molybdenum blue (specific for phosphates) and $\alpha$-naphthol (specific for sugars). Biomass used for the extraction was grown on trypticase soy agar (BBL) at $28{ }^{\circ} \mathrm{C}$ for $24 \mathrm{~h}$. The polar lipid profiles of the three representative isolates tested, KS-SP 11, KS-SP $60^{\mathrm{T}}$ and KS-SDV 19, were very similar. They consisted of the major lipids diphosphatidylglycerol and phosphatidylglycerol. Moderate amounts of three unknown glycolipids, of which two corresponded to GL1 and GL2 as described by Nahaie et al. (1984), were detected. Also, minor to trace amounts of unknown aminolipids were observed. These profiles are in agreement with other Staphylococcus species profiles (Nahaie et al., 1984; Nováková et al., 2010).

An almost-complete fragment of the 16S rRNA gene and partial fragments of the housekeeping genes coding for the $\beta$ subunit of the RNA polymerase $(r p o B)$, the heat-shock protein $60(h s p 60)$, the elongation factor Tu (tuf) and the heat-shock protein DnaJ (dnaJ), were amplified and sequenced according to previously described procedures (for rpoB, hsp60 and tuf, Supré et al., 2009; for dnaJ, Shah et al., 2007), except that other primers were used for $16 \mathrm{~S}$ rRNA gene sequencing (Mergaert et al., 2001; Coenye et al., 1999) (Supplementary Table S2). Forward and reverse sequences were aligned with the Vector NTI Advance 10 software (Invitrogen Life Technologies) and compared to GenBank sequences via the nucleotide-nucleotide BLAST algorithm (http://ncbi.nlm.nih.gov/). For alignment of nucleotide sequences, the CLUSTAL W program (Thompson et al., 1994) was used. Neighbour-joining and maximum-parsimony (Saitou \& Nei, 1987) trees were obtained with the PHYLIP program (Felsenstein, 1989) and drawn with the software TreeView (http://taxonomy.zoology.gla.ac.uk/rod/ treeview.html). DNADIST was utilized for distance analysis according to Kimura's two-parameter model (Kimura, 1980). Bootstrap values were determined based on 1000 replications.

The discriminatory power of the 16S rRNA gene is limited in the genus Staphylococcus (CLSI, 2007; Shah et al., 2007), whereas the housekeeping genes $r p o B, h s p 60$, tuf and $d n a J$ show more variation and are preferred over $16 \mathrm{~S}$ rRNA gene sequencing for species identification (Zadoks \& Watts, 2009). The cut-off values previously reported for species identification were $98.7 \%$ for $16 \mathrm{~S}$ rRNA (Jousson et al., 2007), $94 \%$ for rpoB (Mellmann et al., 2006) and $97 \%$ for $h s p 60$, tuf and dnaJ (CLSI, 2007). For each of the genes, the sequences of the ten isolates were compared against each other. Within each gene, the sequence similarities were high, namely $99.6-100 \%$ for the $16 \mathrm{~S}$ rRNA gene sequence, $99.1-100 \%$ for $d n a J, 99.7-100 \%$ for rpoB, $98.6-100 \%$ for $h s p 60$ and $99.6-100 \%$ for tuf. The overall mean intraspecies divergence per housekeeping gene was $0.7 \%$, which is within the variability noted for Staphylococcus species (Shah et al., 2007). The high similarities therefore indicate that the isolates probably belong to a single species. Neighbour-joining phylogenetic trees based on 16S rRNA (Fig. 1) and dnaJ (Supplementary Fig. S2) gene sequences were constructed. The phylogenetic position of the ten isolates was in the genus Staphylococcus, confirming the previous data. The topology of the maximum-parsimony tree was comparable (not shown). Sequencing of all five genes revealed seven different species to be the closest relatives, namely $S$. haemolyticus, $S$. hominis, S. lugdunensis, S. pasteuri, S. warneri, S. caprae and S. piscifermentans (not shown). Partial phylogenetic trees for the $r p o B, h s p 60$ and tuf genes, in which the unknown cluster and only these closest relatives were included, are shown in Supplementary Fig. S3. Because S. piscifermentans was distant from the unknown cluster in the 16S rRNA gene tree (Fig. 1), this species was not included in the 
partial trees. Within each gene, sequences of the unknowns were compared to those of the three closest relatives based on the 16S rRNA gene (S. haemolyticus, S. hominis and $S$. lugdunensis) and similarities were calculated (Table 1). The similarities obtained were below the cut-off values used previously for species identification, which suggests that the isolates represent a novel Staphylococcus species.
In some phylogenetic trees, namely in those based on $16 \mathrm{~S}$ rRNA, dnaJ and $h s p 60$ gene sequences, the isolates formed a cluster divided into subclusters, with KS-SDV 19 belonging to the smallest subcluster (Fig. 1 and Supplementary Figs S2 and S3b). Therefore, three of the unknown isolates (KS-SP 11, KS-SP $60^{\mathrm{T}}$ and KS-SDV 19), taken from the subclusters and covering the total branch of the isolates in

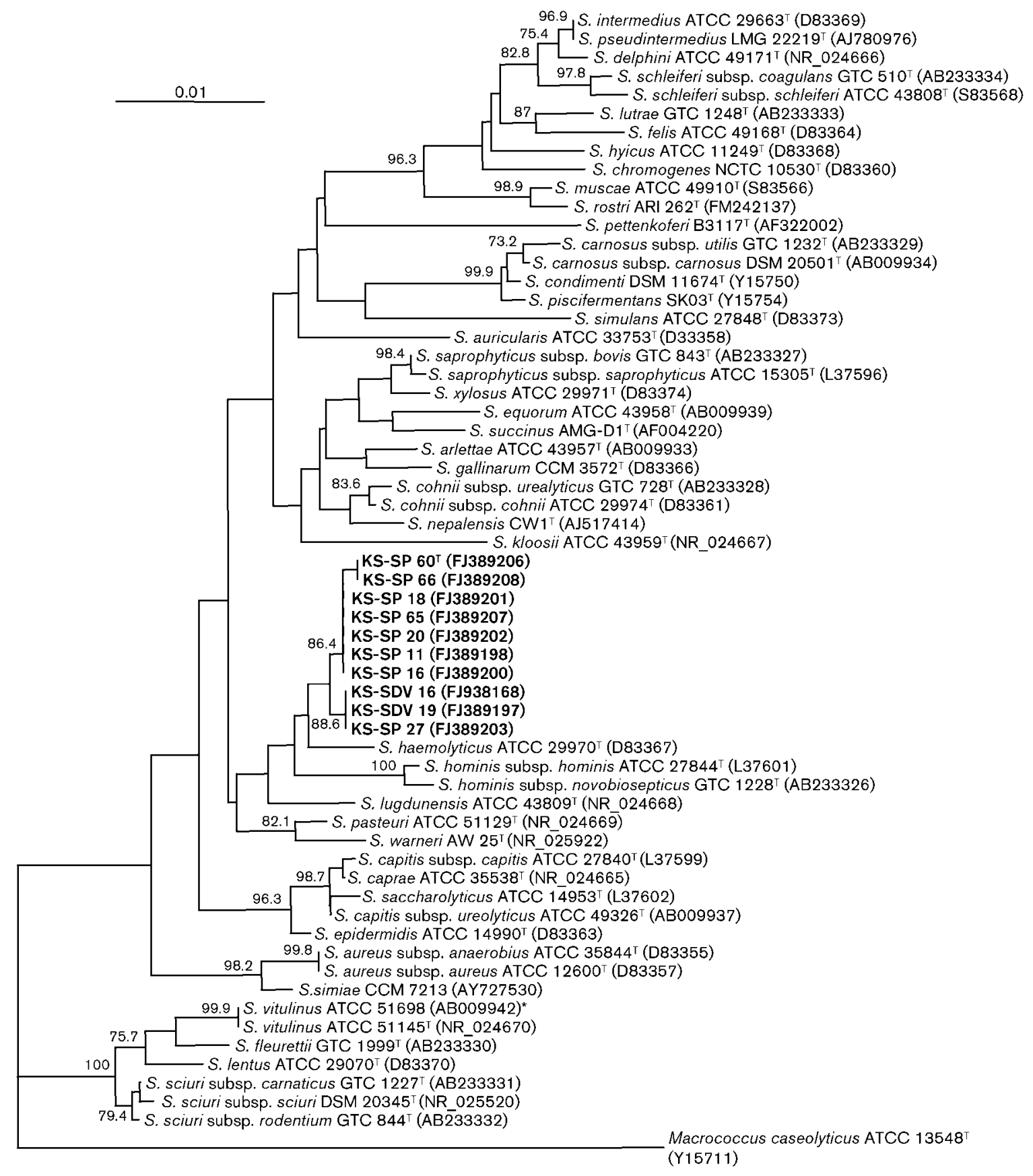

Fig. 1. Phylogenetic tree, constructed using the neighbour-joining method, based on the 16S rRNA gene sequences of strains of Staphylococcus devriesei sp. nov. and reference sequences of Staphylococcus strains available online. Macrococcus caseolyticus ATCC $13548^{\top}$ was chosen as the outgroup. Bootstrap values, calculated from 1000 resamplings, are given at nodes if higher than $70 \%$. Bar, $1 \%$ sequence divergence. *, Type strain of Staphylococcus pulvereri. 
Table 1. Intraspecies and interspecies sequence similarity of the ten strains of Staphylococcus devriesei sp. nov.

Values are mean (range) percentage similarity. Sequences of the ten novel strains were compared with sequences from the type strains of the three phylogenetically most closely related species on the basis of the 16S rRNA gene sequence. Gene-specific cut-off percentages for each gene are given as cited in literature.

\begin{tabular}{|c|c|c|c|c|c|}
\hline Strain $(s)$ & 16S rRNA & $d n a J$ & rpoB & hsp60 & tuf \\
\hline S. devriesei sp. nov. $(n=10)$ & $99.9(99.6-100)$ & $99.6(99.1-100)$ & $99.9(99.7-100)$ & $99.6(98.6-100)$ & $99.9(99.6-100)$ \\
\hline S. haemolyticus LMG $13349^{\mathrm{T}}$ & $99.2(98.6-99.3)$ & $83.4(82.8-84.0)$ & $92.4(92.0-93.3)$ & $90.0(88.3-91.6)$ & $95.5(94.6-98.4)$ \\
\hline S. hominis LMG $13348^{\mathrm{T}}$ & $98.9(98.8-98.9)$ & $82.6(82.2-82.9)$ & $90.7(90.4-91.1)$ & $89.5(88.2-91.2)$ & $94.5(93.3-96.9)$ \\
\hline S. lugdunensis LMG $13346^{\mathrm{T}}$ & $98.8(98.8-98.9)$ & $80.2(79.8-80.9)$ & $89.4(89.0-90.4)$ & $87.4(86.0-89.3)$ & $94.1(93.0-97.6)$ \\
\hline Gene-specific cut-off $(\%)^{*}$ & $98.7^{a}$ & $97.0^{b}$ & $94.0^{c}$ & $97.0^{b}$ & $97.0^{b}$ \\
\hline
\end{tabular}

${ }^{\star}$ Obtained from: $a$, Jousson et al. (2007); b, CLSI (2007); c, Mellmann et al. (2006).

all sequencing trees, were selected for DNA-DNA hybridizations. Hybridization was performed with the type strains of the three phylogenetically most closely related species based on 16S rRNA gene sequence analysis $(S$. haemolyticus LMG $13349^{\mathrm{T}}$, S. hominis LMG $13348^{\mathrm{T}}$ and $S$. lugdunensis LMG $13346^{\mathrm{T}}$ ). DNA was extracted as described by Gevers et al. (2001). DNA-DNA hybridizations were carried out according to a modification of the microplate method (Ezaki et al., 1989) as detailed by Goris et al. (1998) and Cleenwerck et al. (2002). The hybridization temperature was $34{ }^{\circ} \mathrm{C}$. Reciprocal reactions (e.g. $\mathrm{A} \times \mathrm{B}$ and $\mathrm{B} \times \mathrm{A}$ ) showed variations within the limits of the method, i.e. mean SD of $7 \%$ (Goris et al., 1998). DNADNA hybridizations revealed 97-99\% DNA binding between isolates KS-SP 11 , KS-SP $60^{\mathrm{T}}$ and KS-SDV 19. Although KS-SDV 19 belonged to a different subcluster based on 16S rRNA, dnaJ and hsp60 gene sequences, it showed similarly high hybridization with KS-SP 11 and KS-SP $60^{\mathrm{T}}$ and, therefore, hybridization of this strain with type strains of other species was not deemed necessary. There was a low level of DNA binding between isolates KSSP 11 and KS-SP $60^{\mathrm{T}}$ and the type strains S. haemolyticus LMG $13349^{\mathrm{T}}(17 \%)$, S. hominis LMG $13348^{\mathrm{T}}(23 \%)$ and $S$. lugdunensis LMG $13346^{\mathrm{T}}(27 \%)$. These data indicate that the ten isolates belong to a single novel species within the genus Staphylococcus (Wayne et al., 1987).

The DNA base composition (mol\%) of KS-SDV 16, KS-SP $11, \mathrm{KS}-\mathrm{SP} 16, \mathrm{KS}-\mathrm{SP} 20$ and KS-SP $60^{\mathrm{T}}$ was determined in triplicate by HPLC, according to Mesbah et al. (1989), using DNA extraction procedures described by Gevers et al. (2001). The DNA G + C content of KS-SDV 16, KS-SP 11, KS-SP 16 and KS-SP 20 was $33.7 \mathrm{~mol} \%$ and that of KS-SP $60^{\mathrm{T}}$ was $33.3 \mathrm{~mol} \%$. The range of DNA base composition is lower than $2 \mathrm{~mol} \%$, as generally accepted within a single species, and is consistent with that of members of the genus Staphylococcus (Kocur et al., 1971).

Phenotypic characteristics of all ten isolates were obtained using API $50 \mathrm{CH}$ with $\mathrm{CHB} / \mathrm{E}$ medium (bioMérieux), API Staph ID 32 (bioMérieux) and Staph Zym (Rosco) test kits. Tube coagulase (coagulase plasma; Difco Laboratories) and clumping factor (Devriese, 1979) were also examined. The
DNase reaction was assessed using DNase agar (Oxoid). The phenotypic features of the ten isolates were compared with those of the three phylogenetically most closely related species based on 16S rRNA gene sequences ( $S$. haemolyticus, S. hominis and S. lugdunensis). Differentiating biochemical characteristics are listed in Table 2 and individual phenotypes of each isolate are given in

Table 2. Phenotypic characteristics of $S$. devriesei sp. nov. compared with the phylogenetically most closely related Staphylococcus species

Species: 1, S. devriesei sp. nov. (for variable tests, reaction of strain KS-SP $60^{\mathrm{T}}$ in brackets); 2, S. haemolyticus; 3, S. hominis; 4, S. lugdunensis. Closely related species were selected on the basis of the $16 \mathrm{~S}$ rRNA gene sequence. Data for reference taxa were obtained from Freney et al. (1999). +, $90 \%$ or more isolates positive;,$- 90 \%$ or more isolates negative; $a, 11-50 \%$ of isolates positive; $b, 51-89 \%$ of isolates positive; c, $11-89 \%$ of isolates positive; ND, no data available. All tested strains were positive for acetyl methyl carbinol utilization and negative for starch utilization, alkaline phosphatase and $\beta$ galactosidase. Oxidation and fermentation of D-glucose was positive. Acid was produced from D-fructose, maltose, trehalose and L-sorbose. There was no acid production from amygdalin, D-adonitol, arabinose, arabitol, cellobiose, D-fucose, D-xylose, raffinose, D-sorbitol, Dtagatose, xylose, erythritol, gentiobiose, salicin or xylitol. Utilization of glycogen, inositol, inulin, potassium 2-ketogluconate, methyl $\alpha$-Dmannopyranoside, methyl $\beta$-D-xylopyranoside and methyl $\alpha$-Dglucopyranoside was negative.

\begin{tabular}{|lcccc|}
\hline Characteristic & $\mathbf{1}$ & $\mathbf{2}$ & $\mathbf{3}$ & $\mathbf{4}$ \\
\hline Arginine dihydrolase & + & + & $\mathrm{c}$ & - \\
$\begin{array}{l}\beta \text {-Glucosidase } \\
\text { Acid production from: }\end{array}$ & + & $\mathrm{c}$ & - & $\mathrm{ND}$ \\
$\quad$ D-Mannitol & $\mathrm{b}[+]$ & $\mathrm{c}$ & - & - \\
$\quad$ D-Mannose & $\mathrm{a}[-]$ & - & - & + \\
$\quad$ Melezitose & $\mathrm{b}[+]$ & - & $\mathrm{c}$ & $\mathrm{ND}$ \\
D-Ribose & + & $\mathrm{c}$ & - & - \\
Nitrate reduction & $\mathrm{a}[-]$ & $\mathrm{c}$ & $\mathrm{c}$ & + \\
Urease & $\mathrm{b}[+]$ & - & + & $\mathrm{c}$ \\
\hline
\end{tabular}


Supplementary Table S3. Tube coagulase, clumping and the DNase reaction were negative for all isolates. All isolates were considered sensitive to novobiocin.

In conclusion, the data from this study demonstrate that the ten isolates are members of a novel Staphylococcus species, for which the name Staphylococcus devriesei sp. nov. is proposed. In ongoing field studies in Belgium, additional isolates belonging to this species have been detected in milk and on teat apices of dairy heifers and cows.

\section{Description of Staphylococcus devriesei sp. nov.}

Staphylococcus devriesei (de.vrie'se.i. N.L. masc. gen. n. devriesei of Devriese, named in honour of the Belgian microbiologist Dr Luc A. Devriese for his contribution to the taxonomy of staphylococci).

This description is based on the characteristics of nine isolates originating from teat apices and one isolate originating from milk of dairy cows. Cells are Gramstain-positive, non-spore-forming cocci that occur in pairs or small clusters. Colonies are $3-4 \mathrm{~mm}$ in diameter after $48 \mathrm{~h}$ of growth on Colombia blood agar with $5 \%$ sheep blood at $35{ }^{\circ} \mathrm{C}$, have a zone of complete haemolysis of $1 \mathrm{~mm}$ and are grey-yellow, yellow or yellow-orange, smooth and glistening. Coagulase- and oxidase-negative and catalase-positive. Negative for starch utilization and alkaline phosphatase, $\beta$-glucuronidase and $\beta$-galactosidase activities. Acid is produced from D-galactose, lactose, Dribose, sucrose, turanose, D-fructose, maltose, trehalose and L-sorbose. No acid production from melibiose, Lfucose, L-rhamnose, amygdalin, D-adonitol, arabinose, arabitol, cellobiose, D-fucose, D-lyxose, raffinose, D-sorbitol, D-tagatose, xylose, erythritol, gentiobiose, salicin or xylitol. Utilization of glycogen, dulcitol, inositol, inulin, potassium 2-ketogluconate, potassium 5-ketogluconate, pyrrolidonyl aminopeptidase, methyl $\alpha$-D-mannopyranoside, methyl $\beta$-D-xylopyranoside and methyl $\alpha$-D-glucopyranoside are negative. Acid is not produced from D-mannose for eight of the tested strains. Variable acid production is seen from D-mannitol (eight strains positive), melezitose (seven positive) and glycerol (nine positive). Aesculin ferric citrate reaction is weakly positive for nine of the strains, the remaining strain tested negative. Oxidation and fermentation of D-glucose is positive for all tested isolates. Utilization of acetyl methyl carbinol and arginine dihydrolase and $\beta$-glucosidase reactions are positive. Variable reactions are detected for the utilization of arbutin (four strains positive), potassium gluconate (seven positive) and $\mathrm{N}$-acetylglucosamine (seven positive) and urease activity (six positive), as well as reduction of nitrate (four positive). The major fatty acids are anteiso$\mathrm{C}_{15: 0}$, iso- $\mathrm{C}_{15: 0}$, anteiso- $\mathrm{C}_{17: 0}$, iso- $\mathrm{C}_{17: 0}$ and $\mathrm{C}_{18: 0}$.

The type strain, KS-SP $60^{\mathrm{T}}\left(=\mathrm{LMG} 25332^{\mathrm{T}}=\mathrm{CCUG}\right.$ $58238^{\mathrm{T}}$ ), was isolated from the teat apex of a Belgian dairy heifer; its characteristics are in agreement with those given in the species description. In addition, the type strain is positive for acid production from D-mannitol, melezitose and glycerol, acid is not produced from D-mannose, the aesculin ferric citrate reaction is weakly positive, utilization of potassium gluconate, $\mathrm{N}$-acetylglucosamine and arbutin is negative, urease activity is positive and nitrate is not reduced. The DNA $\mathrm{G}+\mathrm{C}$ content of the type strain is $33.3 \mathrm{~mol} \%$. Details of the ten isolates studied are included in Supplementary Table S1.

\section{Acknowledgements}

This study was funded by the Institute for the Promotion of Innovation through Science and Technology in Flanders (IWTVlaanderen) (grant no. 61459) and by the Prime Minister's Services Federal Office for Scientific, Technical and Cultural Affairs, Belgium. Arlette Vandekerckhove, Liesbeth Lebbe and An Coorevits are acknowledged for their excellent technical assistance and Venessa Eeckhaut for her assistance with bootstrap analysis.

\section{References}

Cleenwerck, I., Vandemeulebroecke, K., Janssens, D. \& Swings, J. (2002). Re-examination of the genus Acetobacter, with descriptions of Acetobacter cerevisiae sp. nov. and Acetobacter malorum sp. nov. Int $J$ Syst Evol Microbiol 52, 1551-1558.

CLSI (2007). Interpretive criteria for microorganism identification by DNA target sequencing. Proposed Guideline. CLSI document MM18-P (ISBN 1-56238-646-8). Wayne, PA: Clinical and Laboratory Standards Institute.

Coenye, T., Enevold, F., Vancanneyt, M., Hoste, B., Govan, J. R. W., Kersters, K. \& Vandamme, P. (1999). Classification of Alcaligenes faecalis-like isolates from the environment and human clinical samples as Ralstonia gilardii sp. nov. Int J Syst Bacteriol 49, 405413.

De Vliegher, S., Laevens, H., Devriese, L. A., Opsomer, G., Leroy, J. L., Barkema, H. W. \& de Kruif, A. (2003). Prepartum teat apex colonization with Staphylococcus chromogenes in dairy heifers is associated with low somatic cell count in early lactation. Vet Microbiol 92, 245-252.

De Vliegher, S., Opsomer, G., Vanrolleghem, A., Devriese, L. A., Sampimon, O. C., Sol, J., Barkema, H. W. \& Haesebrouck, F. (2004). In vitro growth inhibition of major mastitis pathogens by Staphylococcus chromogenes originating from teat apices of dairy heifers. Vet Microbiol 101, 215-221.

Devriese, L. A. (1979). Identification of clumping factor negative staphylococci isolated from cows' udders. Res Vet Sci 27, 313-320.

Ezaki, T., Hashimoto, Y. \& Yabuuchi, E. (1989). Fluorometric deoxyribonucleic acid-deoxyribonucleic acid hybridization in microdilution wells as an alternative to membrane filter hybridization in which radioisotopes are used to determine genetic relatedness among bacterial strains. Int J Syst Bacteriol 39, 224-229.

Felsenstein, J. (1989). PHYLIP - phylogeny inference package (version 3.2). Cladistics 5, 164-166.

Freney, J., Kloos, W. E., Hajek, V., Webster, J. A., Bes, M., Brun, Y. \& Vernozy-Rozand, C. (1999). Recommended minimal standards for description of new staphylococcal species. Int J Syst Bacteriol 49, 489502.

Gevers, D., Huys, G. \& Swings, J. (2001). Application of rep-PCR fingerprinting for identification of Lactobacillus species. FEMS Microbiol Lett 205, 31-36. 
Gillespie, B. E., Headrick, S. I., Boonyayatra, S. \& Oliver, S. P. (2009). Prevalence and persistence of coagulase-negative Staphylococcus species in three dairy research herds. Vet Microbiol 134, 65-72.

Goris, J., Suzuki, K., De Vos, P., Nakase, T. \& Kersters, K. (1998). Evaluation of a microplate DNA-DNA hybridization method compared with the initial renaturation method. Can J Microbiol 44, 1148-1153.

Hogan, J. S., Gonzáles, R. N., Harmon, R. J., Nickerson, S. C., Oliver, S. P., Pankey, J. W. \& Smith, K. L. (1999). Laboratory Handbook on Bovine Mastitis, revised edn. Madison, WI: National Mastitis Council.

Jousson, O., Di Bello, D., Vanni, M., Cardini, G., Soldani, G., Pretti, C. \& Intorre, L. (2007). Genotypic versus phenotypic identification of staphylococcal species of canine origin with special reference to Staphylococcus schleiferi subsp. coagulans. Vet Microbiol 123, 238-244.

Kimura, M. (1980). A simple method for estimating evolutionary rates of base substitutions through comparative studies of nucleotide sequences. J Mol Evol 16, 111-120.

Kocur, M., Bergan, T. \& Mortensen, N. (1971). DNA base composition of Gram-positive cocci. J Gen Microbiol 69, 167-183.

Kotilainen, P., Huovinen, P. \& Eerola, E. (1991). Application of gasliquid chromatographic analysis of cellular fatty acids for species identification and typing of coagulase-negative staphylococci. J Clin Microbiol 29, 315-322.

Mellmann, A., Becker, K., van Eiff, C., Keckevoet, U., Schumann, P. \& Harmsen, D. (2006). Sequencing and staphylococci identification. Emerg Infect Dis 12, 333-336.

Mergaert, J., Verhelst, A., Cnockaert, M. C., Tan, T.-L. \& Swings, J. (2001). Characterization of facultative oligotrophic bacteria from polar seas by analysis of their fatty acids and $16 \mathrm{~S}$ rDNA sequences. Syst Appl Microbiol 24, 98-107.

Mesbah, M., Premachandran, U. \& Whitman, W. B. (1989). Precise measurement of the $\mathrm{G}+\mathrm{C}$ content of deoxyribonucleic acid by highperformance liquid chromatography. Int J Syst Bacteriol 39, 159-167.

Nahaie, M. R., Goodfellow, M., Minnikin, D. E. \& Hajek, V. (1984). Polar lipid and isoprenoid quinine composition in the classification of Staphylococcus. J Gen Microbiol 130, 2427-2437.

Nováková, D., Pantůček, R., Hubálek, Z., Falsen, E., Busse, H.-J., Schumann, P. \& Sedláček, I. (2010). Staphylococcus microti sp. nov., isolated from the common vole (Microtus arvalis). Int J Syst Evol Microbiol 60, 566-573.
Piepers, S. L., De Meulemeester, L., de Kruif, A., Opsomer, G., Barkema, H. W. \& De Vliegher, S. (2007). Prevalence and distribution of mastitis pathogens in subclinically infected dairy cows in Flanders, Belgium. J Dairy Res 74, 478-483.

Saitou, N. \& Nei, M. (1987). The neighbor-joining method: a new method for reconstructing phylogenetic trees. Mol Biol Evol 4, 406425.

Schukken, Y. H., Gonzalez, R. N., Tikofsky, L. L., Schulte, H. F., Santisteban, G. C., Welcome, F. L., Bennett, G. J., Zurakowski, M. J. \& Zadoks, R. N. (2009). CNS mastitis: nothing to worry about? Vet Microbiol 134, 9-14.

Shah, M. M., lihara, H., Noda, M., Song, S. X., Nhung, P. H., Ohkusu, K., Kawamura, Y. \& Ezaki, T. (2007). dnaJ gene sequence-based assay for species identification and phylogenetic grouping in the genus Staphylococcus. Int J Syst Evol Microbiol 57, 25-30.

Supré, K., De Vliegher, S., Sampimon, O. C., Zadoks, R. N., Vaneechoutte, M., Baele, M., De Graef, E., Piepers, S. \& Haesebrouck, F. (2009). Use of tRNA-intergenic spacer PCR combined with capillary electrophoresis to identify coagulase-negative Staphylococcus species originating from bovine milk and teat apices. J Dairy Sci 92, 3204-3210.

Thompson, J. D., Higgins, D. G. \& Gibson, T. J. (1994). CLUSTAL W: improving the sensitivity of progressive multiple sequence alignment through sequence weighting, position-specific gap penalties and weight matrix choice. Nucleic Acids Res 22, 4673-4680.

Tindall, B. J. (1990a). Lipid composition of Halobacterium lacusprofundi. FEMS Microbiol Lett 66, 199-202.

Tindall, B. J. (1990b). A comparative study of the lipid composition of Halobacterium saccharovorum from various sources. Syst Appl Microbiol 13, 128-130.

Wayne, L. G., Brenner, D. J., Colwell, R. R., Grimont, P. A. D., Kandler, O., Krichevsky, M. I., Moore, L. H., Moore, W. E. C., Murray, R. G. E. \& other authors (1987). International Committee on Systematic Bacteriology. Report of the ad hoc committee on reconciliation of approaches to bacterial systematics. Int J Syst Bacteriol 37, 463-464.

Zadoks, R. N. \& Watts, J. L. (2009). Species identification of coagulase-negative staphylococci: genotyping is superior to phenotyping. Vet Microbiol 134, 20-28. 